レター

\title{
建築現場に適応する内装資材自動搬送ロボットの構造提案
}

\author{
奥 畑 一 男*1 猪 野 真 吾*1 溝 㴊 宣 誠*1 \\ 岡 村 甫*2 王 碩 玉*2 楊 光*2
}

\section{Proposal of Structure of Automatic Interior Material Transfer Robot Adapting to Construction Site}

\author{
Kazuo Okuhata*1, Shingo Ino*1, Yoshinobu Mizobuchi*1, Hajime Okamura*2, \\ Shuoyu Wang*2 and Guang Yang*2
}

\begin{abstract}
Various types of material handling robots (AGVs, Automatic Guided Vehicles) have been developed to improve the work efficiency at construction sites, yet neither of them has been popularized. In this work, we present a gate-type robot suitable for automatic material handling during interior construction. The effectiveness of the robot has been evaluated through experiments in real construction sites. A gate-type robot has the following three characteristics: (i) the payload-weight ratio is near 5; (ii) picking and placing of randomly located carts (loaded with building materials) is possible; (iii) complex environments at construction sites can be navigated smoothly without unnecessary movement.
\end{abstract}

Key Words: AGV, Automatic Transfer, Autonomous Transport, Construction Site, Material Transportation

1. 背景

本報告では，建築現場での作業効率向上を目的とし，不定で 複雑な建築現場環境に扔いて, 多種多様の建築資材を安定して 自動搬送できる新型ロボットの構造を提案し，試作機の性能測 定実験と現場実証実験の結果を報告する。

建物を建築する過程において，内装工事はプロジェクトの中 で大きな割合を占める重要な工程であり $[1]$, 施工に必要な内装 資材を定められた地点に都度搬送する必要がある。搬送作業の 難点として，1）人的労力と時間の確保，2）力と力のモーメン 卜を適切に運用するノウハウ，3）複雑で日々変化する現場環境 に適応できる経験，の 3 点が挙げられる. 難点 1）の例として, 内装用石膏ボードを大量に積載した台車の総重量は $1,000[\mathrm{~kg}]$ 近くになり，それを動かすには通常 3 人程度の作業者を必要と する。 それらが大量に存在する場合，搬送作業だで多くの時 間が必要となる。難点 2) では, 資材には長さが数 $[\mathrm{m}]$ に及ぶ ものや不定形物もあり, 単に重心を動かす力だけではなく, 資 材の形状や状態に応じて姿勢を制御する力のモーメントを適切 に運用しなければならない。難点 3) では, 定物定置で良い倉 庫や工場と異なり，建築現場では常に多数の重機が縦横無尽に 稼働し，大量の資材がフロア上に煩雑に据置されており，その 環境は常に一定ではない。その環境下でほかの資材や施設に衝 突させて破損させないよう, 複数の作業員で周辺状況に注意し

原稿受付 2020 年 8 月 18 日

*1有限会社サット・システムズ

$* 2$ 高知工科大学

${ }^{* 1}$ SATT SYSTEMS Ltd.

${ }^{* 2}$ Kochi University of Technology

口 本論文は有用性（実証実験分野）で評価されました。

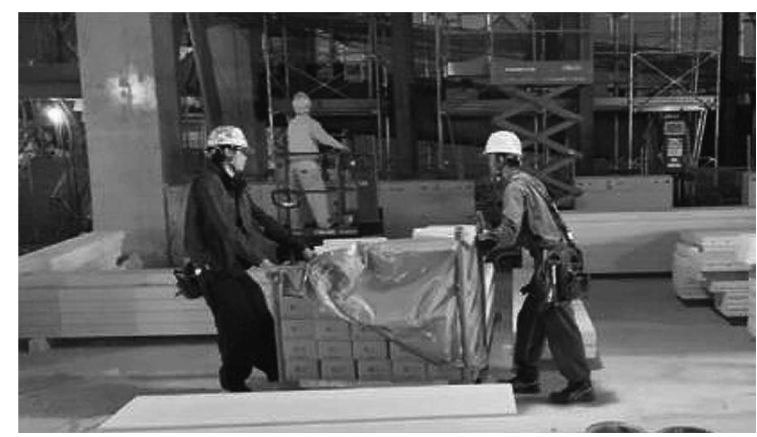

Fig. 1 Environmental changes and careful work

て慎重に作業する必要がある（Fig. 1)。これらの難点から，搬 送業務に特化した揚重業者が存在し, 作業を一手に担っている. 現在，建築業では高齢化問題により将来の若い作業員不足に直 面し, 労働力確保が難しくなっている [2]. 揚重業者も例外では なく, 資材搬送にかかる時間は工事の作業効率に直接影響を与 えるため, 自動省力化による効率向上が強く求められている.

建築業界では様々な資材自動搬送システム（以下「AGV」）が 開発されているが，まだ普及には至っていない. 主な問題点と して，1）多種多様な資材搬送に最適なメ力構造開発，2）不定 で複雑な環境に適応する自律制御の構築，が難しいことが考え られる. 本報告では問題点 1) を解決できるメカ構造を提案し, メカニズムの特徵を説明し, 実験による性能と現場での有用性 を示す. 問題点 2）に関する詳細な報告は文献 [7] で説明する.

\section{2. 代表的既存構造}

メカ構造設計にあたり，代表的な搬送装置の機体構造，およ 
び特徵について調査し，開発の参考とした。搬送装置には人を 運ぶものと物を運ぶものがあるが，物である内装資材を運ぶこ とに適すると思われる 4 タイプの構造をピックアップした.

\section{1 吊り上げタイプ}

クレーンのように資材を吊り上げて搬送する方法である (Fig. 2)，基本的に吊りロープは 1 本であり，加速や停止時 に慣性力で資材が摇れ動くことになる，運転を自動化し，高速 搬送するには摇れ止め制御が必要となり，速度，重心，ロープ 長などを常に監視し，フィードバックしなければならない $[3]$. また，クレーン運転免許と玉掛け資格が必要になる可能性があ り，容易に運用できるシステムにならない．

\section{2 リフトアップタイプ}

機器が資材の下に潜り込み，昇降装置で持ち上げて搬送する 方法である (Fig. 3). 機器のサイズが資材の水平方向面積内に 収まれば，狭い通路を走行するには有利である。しかし，Fig. 1 のように建築現場では床上に直接資材を置くことが多く，機器 の超低床設計が求められる，また，走行姿勢の安定化には資材 の重心を検知する力覚センサが必要となる $[4]$ など, 構造設計の ハードルが高い.

\section{3 フォークリフトタイプ}

フォークを資材の下に挿し込み，持ち上げて搬送する方法で ある（Fig.4)。搬送資材を垂直方向に積み重ねたり，棚上に持 ち上げたりするのに適している。一方，資材の過積載や重量の 片寄り，マストの高位置持ち上げ，急旋回などの複合的な要因 による転倒が発生する可能性がある [5]. 運転の自動化にはそれ らの要因を検知する多数のセンサと, 重心を安定させる高度な 制御が必要となり, 安全性を高めるのが難しい.

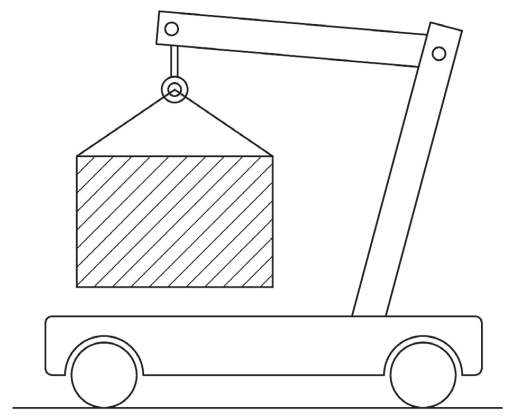

Fig. 2 Hang up type

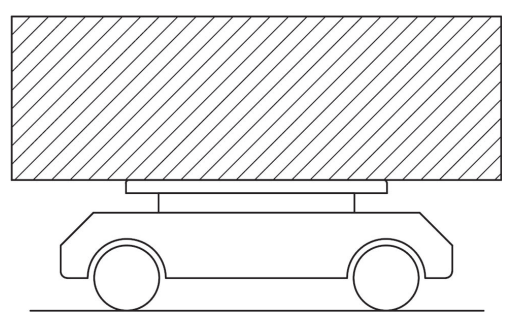

Fig. 3 Lift up type

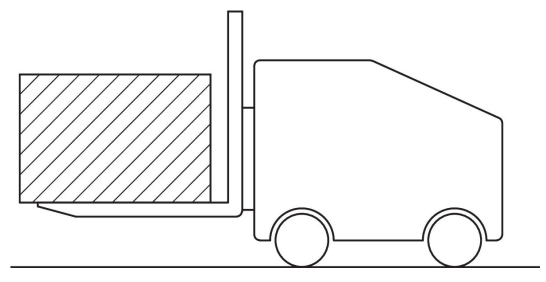

Fig. 4 Forklift type

\section{4 牽引タイプ}

トレーラーのように資材を铱引して搬送する方法である (Fig. 5). 資材を直接持ち上げないため，重量の大きい資材を 搬送しやすく，機器の出力や重量を小さくできる，一方，前後 の全長が長くなり，大きな内輪差や後退時のジャックナイフ現 象が発生する [6]. 運転の自動化において, 安全な走行軌道を追 従する制御が確立できれば運用しやすい。

\section{5 調査のまとめ}

前節 2.1〜3 は機器が直接資材を持ち上げるため, 高い剛性と 高出力のモー夕等が必要となり, 機器の大型化と高重量化につ ながってしまう． 2.4 節の拣引方式にて, 機器が小型軽量で, 資 材を連結した状態でも省スペースで小回りが利き, 重心が走行 中心に近く, 走行状況による重心位置変化が小さければ運転自 動化の制御構築も容易になり, 建築現場に適していると考え, そ れらを実現できるメカ構造を設計することとした。

\section{3. 採 用 構 造}

「物を運ぶ」とは物の姿勢を制御しながら物の重心を動かす ことである。一般的に，小さな力で大きなものを動かせること が望まれる，建築現場の環境と，前節の調査結果を踏まえて下 記 8 項目の要素を洗い出し, 総合的に考慮した結果「門型構造 (Fig. 6-1)」を採用したこと, およびその特徴について報告する. (1)最大搬送重量 / AGV 自重の值を大きくする．資材の垂直荷 重がAGVにかからないようにする.

(2)荷取と荷置動作を簡易な機構で容易に行う.

(3)水平搬送のみ行う. 垂直搬送はエレベータに乗り込むことで 実現しリフト動作はしない.

(4)水平面において多様な資材の姿勢を安定させるため, 力点と 資材重心の距離を大きくする。

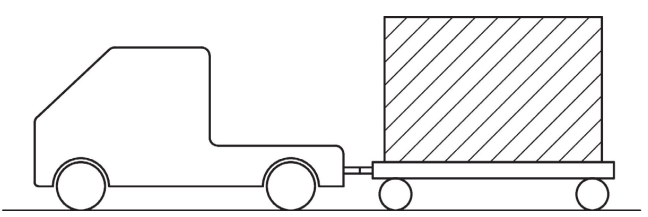

Fig. 5 Tow type

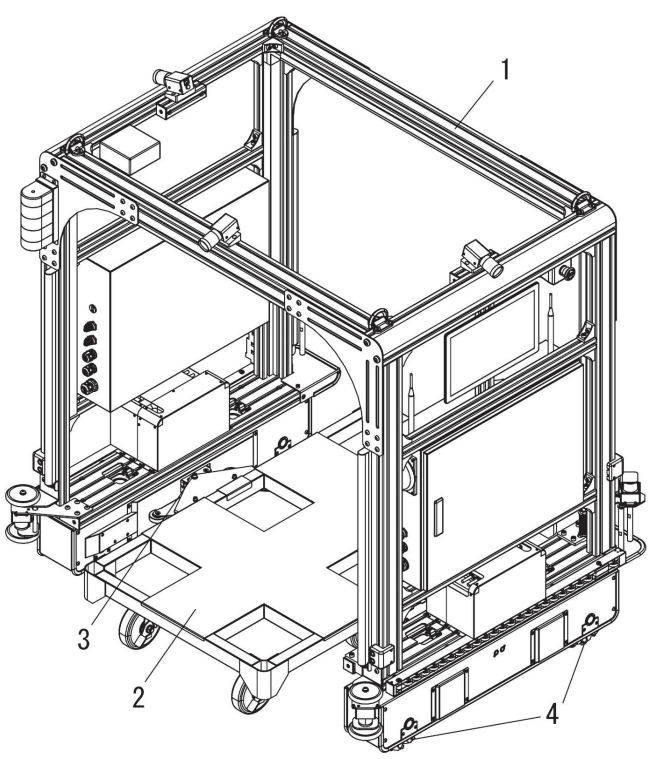

Fig. 6 Machine appearance 


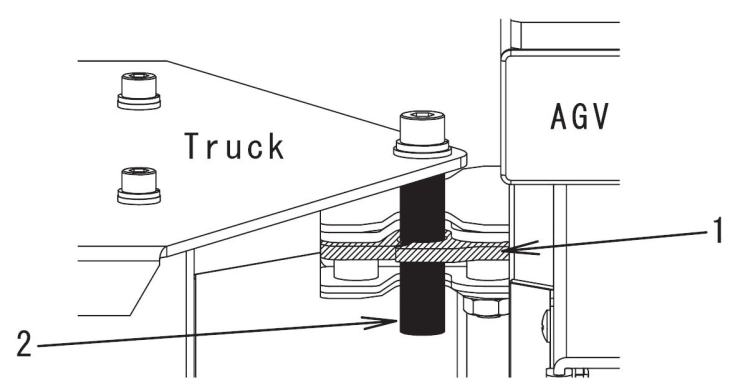

Fig. 7 Connection part details

(5)小さな力で搬送できるよう，作用点と資材重心の距離を小さ くし，力点の配置は資材重心に対して対称にする.

(6)特に AGV の幅サイズを小さくし，資材の幅に近づけて狭い 通路を走行しやすくする.

(7)全方向移動により任意の姿勢で任意の方向に走行し, 複雑な

経路を走行可能にする。

8現場内の段差を乗り越え，傾斜地面を登坂できる.

(1)と (3)について，搬送台車（Fig. 6-2）に資材を載せて斢引す る手法とし，資材の重量を搬送台車がすべて受けることにより， AGVにはその垂直荷重が掛からないようにした，それにより， フレーム構造設計の簡易化, 低出力の駆動輪モー夕採用，およ びリフト装置等を省くことによって車体の軽量化を実現してい る. 実測值として自重 $200[\mathrm{~kg}]$ の AGV は 1,000 [kg]の資材を 搬送可能で, 最大搬送重量 $/ \mathrm{AGV}$ 自重 $=5$ となって抢り, 効 率が良い。

(2)について，AGV 内側に設けた左右対称の連結機構（Fig. 63）が，連結金具を装着した搬送台車と連結することにより，容 易な荷取と荷置動作を実現している。連結機構には電磁ソレノ イドによって開放動作をコントロールできるラッチングロック 機構を備えて㧍り（Fig. 7-1），搬送台車に取り付けた連結金具 両端の連結ピン（Fig. 7-2）がラッチングロックに挿入されるこ とで自動的にロックし, 連結される。 その状態から電磁ソレ, イドによってロックを開放することにより，連結を解除できる.

(4)と(5)ついて, AGV は前後左右対称形状に設計して打り 重心は中央にある。また，4輪の交点が走行中心となり，重心と ほぼ同位置にある。さらに，連結した搬送台車も積載した資材 に極端な偏りが無ければ重心はほぼ中央となる，それらすべて が近いポイントに集まることで, 非常に高い走行性能を発揮し， 資材の姿勢制御と重心移動の容易さを実現している（Fig. 8).

(6)について，門型構造により AGVの内側に資材を抱え込む ことで全幅を抑えている．AGV 内幅は内装工事によく使用さ れる石膏ボードが入る幅とし，AGV 外幅は極力小さく設計する ことで人力搬送時に必要な幅スペースと大差なくしており，狭 い通路での走行が可能なことを実現している.

(7)について，AGVの駆動輪にはメカナムホイールを採用し ている（Fig. 6-4)。それにより，旋回半径を小さくでき，左右 移動，斜め移動，㧍よび定点回転が可能となり，狭い通路の走 行や，エレベータへの乗り込み等の容易さを実現している.

8にについて, Fig.7の連結部に一定の遊びを確保している. そ れにより, AGV と搬送台車の高低差と角度差を吸収することが できる，例えば，登りスロープで先に搬送台車の前車輪がスロー プに差し掛かると，搬送台車の前側だけが浮き上がる。しかし， 連結部の遊びにより高低差と角度差を吸収し，連結部にねじれの 力が加わるのを防いでいる (Fig. 9). また，メカナムホイール

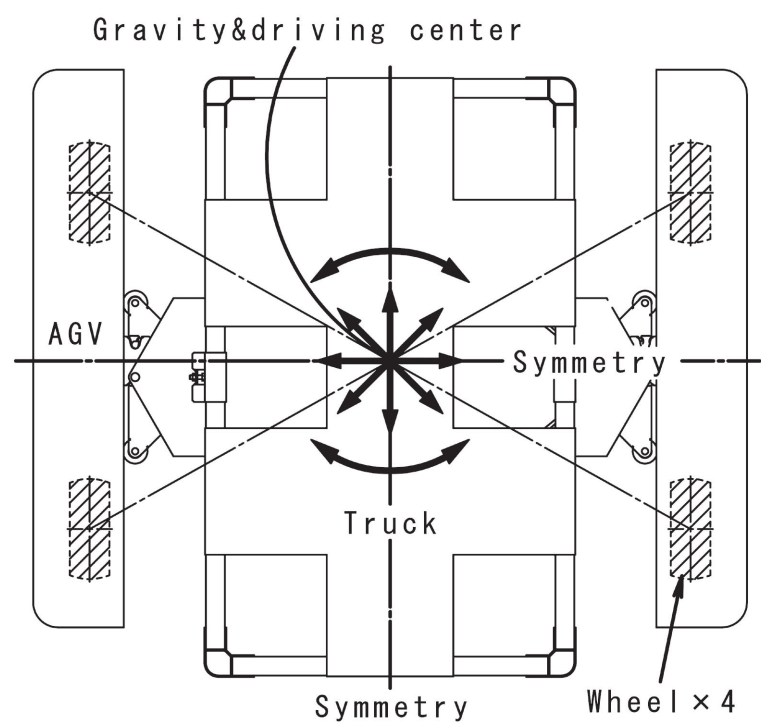

Fig. 8 Top view

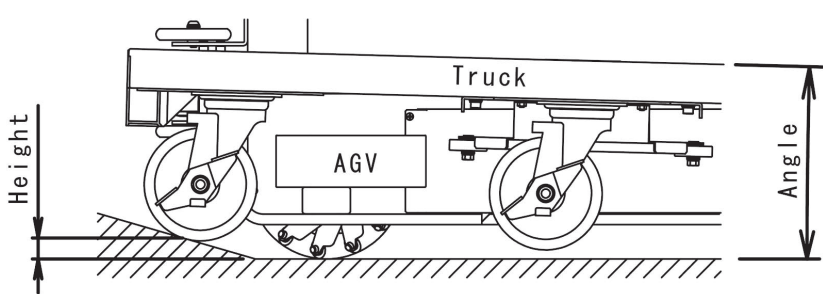

Fig. 9 Absorption of angle difference

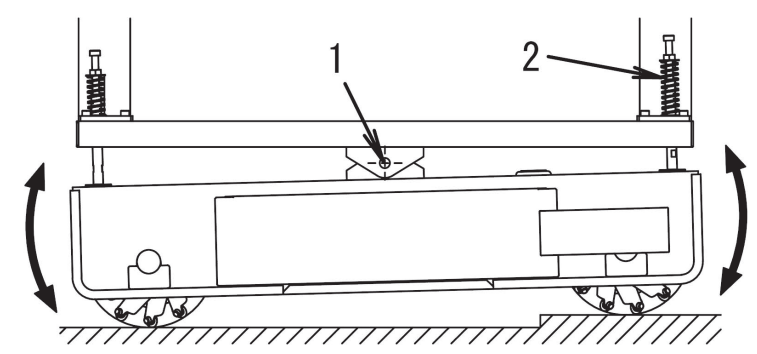

Fig. 10 Suspension mechanism

4 輪のうち片側 2 輪に車軸懸架式のサスペンション機構を設けて いる. 2 輪を繋げるフレームの中央に回転軸構造（Fig. 10-1） と両端に衝撃吸収用スプリングを設け（Fig. 10-2)，その軸を中 心にフレームが最大 $\pm 5^{\circ}$ 傾き, 段差を吸収して常にメカナムホ イール 4 輪を接地させることができる.

\section{4. 性能測定実験と現場実証実験}

実験を二つの段階に分け，第一段階として実機性能が設計目 標性能に達しているか性能測定実験を実施した。項目と目標値 は建築施工業関係者にヒアリングし, 下記のとおり設定した。

(1) 最大牽引重量：建築現場でよく使用される平台車の最大積載 重量が $1,000[\mathrm{~kg}]$ であり，その数值を目標とする.

(2) 最大走行速度：1,000 [kg] の資材を人が搬送する際の速度が 2 $\sim 3[\mathrm{~km} / \mathrm{h}]$ であり, それと同等の $40[\mathrm{~m} / \mathrm{min}]$ を目標とする.

(3)乗り越え溝幅: 建築現場には排水やケーブル収納用等で幅が 最大 $50[\mathrm{~mm}]$ 程度の溝が存在し，それを乗り越える必要があ るため, その数值を目標とする.

(4)乗り越え段差: 建築現場には最大 $20[\mathrm{~mm}]$ 厚さのベニヤ板に よる養生やスロープが存在し，そ扎を乗り越える必要がある 
Table 1 Performance test results

\begin{tabular}{|c|c|c|c|}
\hline \multicolumn{2}{|c|}{ Item } & $\begin{array}{c}\text { Target } \\
\text { value }\end{array}$ & $\begin{array}{c}\text { Measured } \\
\text { value }\end{array}$ \\
\hline \hline (1) & Maximum towing weight [kg] & 1000 & 1000 \\
\hline (2) & Maximum running speed [m/min] & 40 & 36 \\
\hline (3) & Overcoming the groove [mm] & 50 & 30 \\
\hline (4) & Overcoming the steps [mm] & 20 & 15 \\
\hline (5) & Slope climbing [\%] & 10 & 10 \\
\hline (6) & Continuous operating time [min] & 240 & 180 \\
\hline \multirow{2}{*yyy}{ (7) } & Successful for take luggage [times] & 30 & 30 \\
\cline { 2 - 4 } & Successful for put luggage [times] & 30 & 30 \\
\hline (8) & Move in all directions [] & 360 & $30 \mathrm{i}$ \\
\cline { 3 - 4 } & & &
\end{tabular}

ため, その数值を目標とする.

(5)傾斜登坂：建築現場には $10 \%$ 程度の傾斜が存在し，それを登 坂できる必要があるため，その数值を目標とする.

(6)連続稼働時間：1 日にトータル 8 時間稼働させ，途中の充電 回数は極力少なくしたいとの要望があり，充電回数が 1 回で すむ 4 時間 $=240[\mathrm{~min}]$ を目標とする。

(7)荷取・荷置動作：荷取と荷置動作の失敗率が高いと自動運転 時の不安となるため, それぞれ 30 回連続で動作成功するこ とを目標とする。

(8)全方向走行性能：任意の姿勢で全方向に走行できるか確認す るが，360 度にわたって連続的に測定できないため，30 度ず つ 12 分割を目標とする.

実験結果を Table 1 に示す。設定目標に達していない結果 について考察する. (2)〜 (4)は 1,000 [kg], (5)は $500[\mathrm{~kg}]$ の資材 を牽引状態で測定した結果である。(2)は目標值より少し小さい 数值となったが，煩雑な建築現場ではそれほど速度が出せない ため, 許容範囲と判断された. (3)と(4)は目標值の 7 割程度とな り,よく観察すると AGVのメカナムホイールではなく, 資材 を載せた搬送台車の車輪が溝や段差を乗り越えられなかったこ とが分かった，当面は，現場の走行経路側で段差を小さくする 等の対策を施すか，搭載する資材の重量を小さくする対策を取 ることにした。(6)も目標值の 7 割程度となったが，搭載してい るリチウム電池が約 1 時間で高速充電可能であり, 充電回数が 2 回でも問題ないと判断された。ほかの項目は目標值を達成し ており，初号機としては一定の結果が出せたと考える.

第二段階として，実際の建築現場で現場検証実験を夜間に実 施した（Fig. 11）。現場の経路を走行し，傾斜や段差をどの程 度乗り越えられるかを重点的に検証した。その際，夜間照度が 小さいことによる $\mathrm{AR}$ マーカー誤認識等，現場ならではの問題 を確認した。これらについては今後も現場実証実験を継続し,

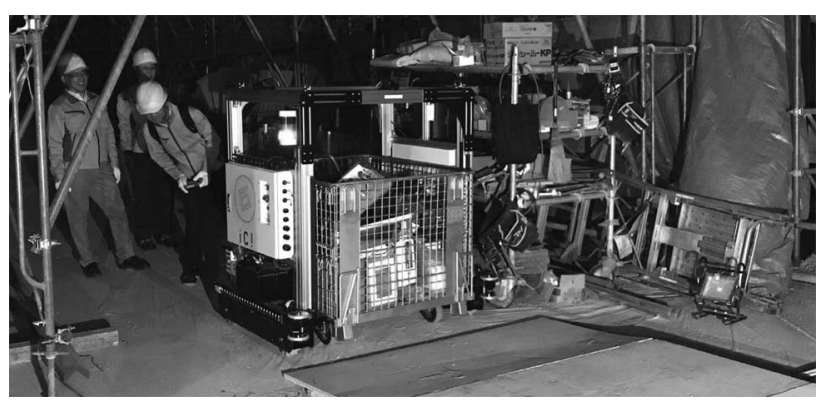

Fig. 11 Field test scene

対策方法を検討していく．本運用を想定した自動運転システム の有用性については，文献 [7] の自律化制御アルゴリズムを実装 し，一台車あたり 40 缶 $\times 15[\mathrm{~kg}]=600[\mathrm{~kg}]$ の塗料を搬送台車 に積載し，搬送実験を実施して検証した。その詳細と結果につ いては文献 $[7]$ をご参考いただきたい.

\section{5. ま ぬ}

本報告では，建築現場における作業効率向上，および労働力 不足の問題解決に貢献する資材自動搬送システムの開発におい て, 多種多様の建築資材の自動搬送に適した $\mathrm{AGV}$ の構造を提 案し, その特徵と性能，および現場での有用性を示した．今後 の最終目標である実用化を目指し，現場の粉塵や夜間照度等の 環境対策，長期稼働による機器の耐久性確認，安全対策や法令 対応等の課題点解決を図るため, 研究を継続する.

\section{参考文 献}

[1] A. Ahmadian F.F, A. Akbarnezhad, T.H. Rashidi and S.T. Waller: "Importance of Planning for the Transport Stage in Procurement of Construction Materials," 31st International Symposium on Automation and Robotics in Construction and Mining (ISARC2014), pp.460-467, 2014.

[ 2 ] N. Muramatsu and H. Akiyama: "Super-Aging Society Preparing for the Future," The Gerontologist, vol.51, no.4, pp.425432,2011

[ 3 ] 森下嚴：“走行クレーン運転自動化のための振れ止め制御”, 計測自動 制御学会論文集, vol.14, no.6, pp.739-744, 1978.

[ 4] 中村陽介, 前山祥一, 田中豊：“リフトアップ型重量物搬送ロボット の開発”, ロボティクス・メカトロニクス講演会講演概要集, pp.2P1I02_1-4, 2007.

[5]笠原美左和：“フォークリフトの重心位置と転倒の関係”, 東京都立産 業技術高等専門学校研究紀要, vol.11, pp.100-105, 2017.

[ 6 ] 三平満司：“厳密な線形化とそのけん引車両の軌道制御への応用”, 計 測と制御, vol.31, no.8, pp.851-858, 1992.

[ 7 ] 楊光, 王碩玉, 岡村甫, 猪野真吾, 奥畑一男, 溝㴊宣誠：“資材自動 搬送ロボットの自律化制御”, 第 38 回日本ロボット学会学術講演会 予稿集 DVD-ROM, 1F1-07, 2020. 